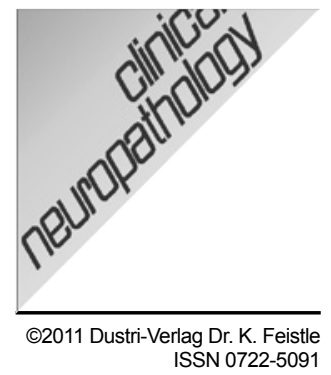

DOI 10.5414/NP300376

\title{
Ganglioneuroma of the sphenoid wing: a case report and literature review
}

\author{
E. Aktüre ${ }^{1}$, M.S. Salamat ${ }^{2}$, H. Korkmaz ${ }^{1}$ and M.K. Başkaya ${ }^{1}$ \\ ${ }^{1}$ Department of Neurological Surgery, and ${ }^{2}$ Department of Pathology and \\ Laboratory Medicine, School of Medicine and Public Health, University of \\ Wisconsin, Madison, WI, USA
}

\section{Key words ganglioneuroma - neural crest derived tumor - sphenoid wing - neuroblastoma - cal- varial tumor}

Received

January 22, 2011; accepted in revised form June 23, 2011

\section{Correspondence to} M.K. Başkaya, MD Department of Neurological Surgery, University of Wisconsin, School of Medicine Building K4/822 CSC, 600 Highland Ave., Madison, WI 53792, USA

m.baskaya@ neurosurg.wisc.edu
Abstract. Ganglioneuromas (GNs) are well-differentiated, slow-growing, benign tumors that are quite rare and usually found in the posterior mediastinum and retroperitoneum. They are composed of ganglion and Schwann cells and their origin remains in dispute. GNs have been reported as intraosseous lesions, such as in temporal and orbital bones. There are rare reports of intracranial lesions, mostly in the pituitary fossa. Most GN patients are children and are clinically asymptomatic. Diagnosis of GN requires histopathologic evaluation since no specific clinical or radiologic diagnostic features have been identified. We report the case of a 35-year-old man with recurrent sinusitis whose radiologic workup revealed a lytic right sphenoid wing lesion with microcalcifications. He underwent gross-total resection of the lesion and the pathologic findings were diagnostic of ganglioneuroma. To the best of our knowledge, this is the first reported case of sphenoid wing GN. The nature and origin of this tumor are discussed, and the GN literature is reviewed.

\section{Introduction}

Ganglioneuromas (GNs) are benign tumors of the peripheral nervous system that are seldom seen in the cranial bones or intracranially. They are composed of mature ganglion cells, occasional satellite or "capsular" cells, unmyelinated axons and Schwann cells [1]. While the origin of GNs remains unclear, such tumors have been observed to arise from maturation of neuroblastomas either spontaneously or particularly, after chemoradiotherapy [2, 3]. However, the distribution differences between neuroblastomas and GNs indicate that de novo development of these tumors exists and is more common. When compared to other benign tumors of the peripheral nervous system such as schwannomas and neurofibromas, GNs are quite rare [4].

Whether arising in the soft tissue or bone, GNs can increase in size and cause compression of adjacent tissue [5]. Intraosseous locations include long bones, vertebrae and cranium [5]. Cranial locations include the orbit and the temporal bones $[6,7,8]$. Vertebral locations include the sacrum and craniocervical junction. Reported intracranial cases are in the older literature and mostly intrasellar $[9,10]$. Based on descriptions given in the older literature, many of these intracranial tumors are more consistent with gangliogliomas, hamartomas and metaplastic neurons in pituitary adenomas.

Additionally, familial disposition as well as an association with neurofibromatosis, Turner Syndrome and multiple endocrine neoplasia syndrome Type-B has been reported [11]. Rarely malignant transformation has been reported either spontaneously or after radiotherapy $[12,13,14]$. Some rare cases of GN are found to secrete sufficient quantities of vasoactive intestinal polypeptide (VIP), vanilmandelic acid (VMA) and homovanilic acid (HVA) to cause flushing, diarrhea and other symptoms of catecholamine excess [15].

These slow growing benign tumors are not always symptomatic but if symptomatic, it is usually due to compression of autonomic or somatic peripheral nerves. In this paper, we present a right sphenoid wing GN that was found incidentally in a 35-year-old man.

\section{Clinical summary}

A 35-year-old man who had recently undergone septoplasty and bilateral turbinate 


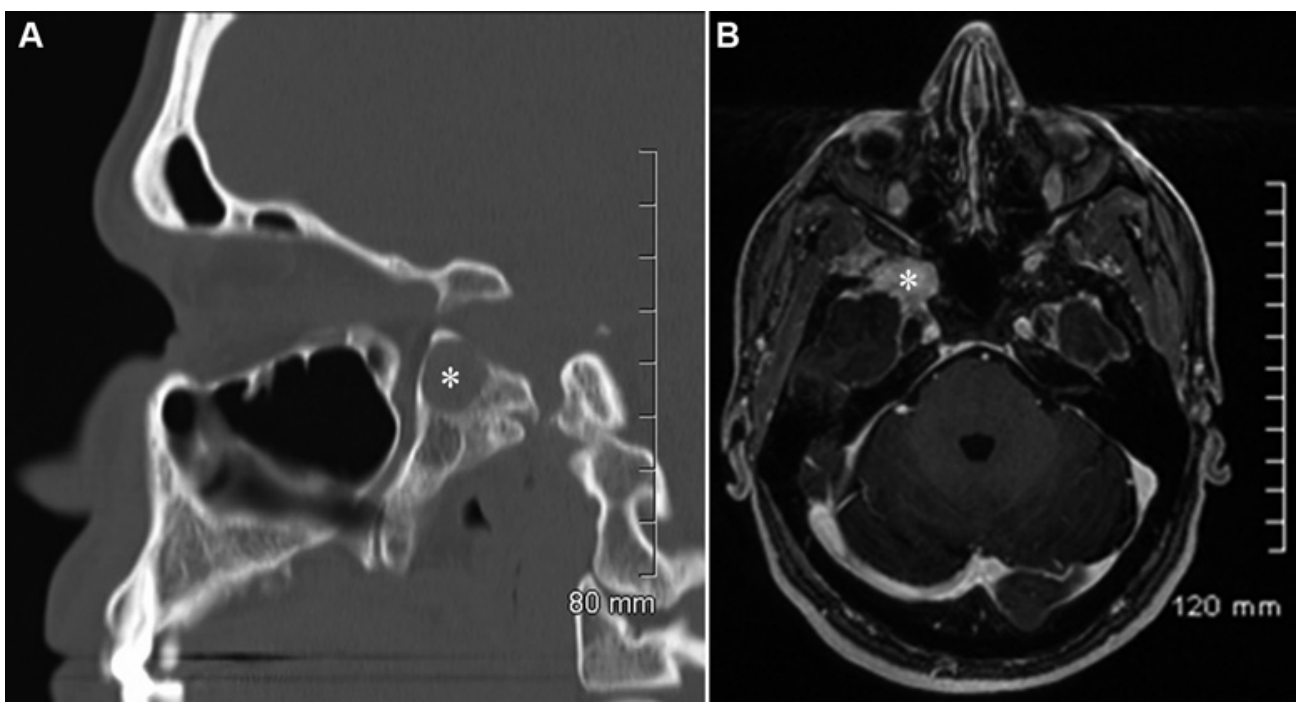

Figure 1. A: Sagittal reformats of the axial non-contrast CT scan revealing the well-demarcated, oval lesion (asterisk) at the sphenoid bone. B: Post-contrast fat saturated axial T1-weight cranial MRI revealing enhancing well-demarcated lesion (asterisk) within the right sphenoid wing around the foramen rotundum.

reduction for frequent episodes of sinusitis was found to have a lytic lesion with smooth borders in the right sphenoid wing on preoperative computerized tomography $(\mathrm{CT})$ scan. After surgery, he was referred for neurosurgical evaluation of the asymptomatic mass. No abnormality was found on the general or neurological examination. Cranial nerve examination in particular showed that facial sensation was intact.

\section{Radiology}

CT scan of the head revealed a fibroosseous, well-demarcated lesion in the right sphenoid wing with remodeling and sclerosis of the adjacent bone (Figure 1A). Magnetic resonance imaging (MRI) also revealed a right sphenoid wing lesion measuring approximately $3 \mathrm{~cm}$ in the long axis extending inferiorly to pterygoid plate and superiorly to the sphenoid wing with some bone remodeling (Figure 1B). It was low in signal intensity on non-contrast $\mathrm{T} 1$-weighted images, heterogeneously isointense on T2-weighted sequences and demonstrated prominent enhancement. The right foramen rotundum appeared involved by the lesion. Differential diagnosis included intraosseous meningioma, metastatic tumors and granulomatous infection.

\section{Surgery}

Due to uncertainty regarding the nature of this lesion, the patient elected for excisional biopsy. He underwent a right cranioorbital approach for microsurgical gross total resection of the lesion. Extradural dissection was performed and the dura was reflected from the greater wing of the sphenoid bone to expose the lesion. The V2 and V3 branches of the trigeminal nerve were identified, and the lesion was found near the foramen rotundum. The trigeminal ganglion and/or trigeminal recess (Meckel's cave) was not exposed since the lesion was not reaching posteriorly. The V2 branch of the trigeminal nerve was severely compressed in the foramen by the tumor. However, no nerve infiltration was observed. Nerve decompression was achieved by microsurgical resection of the tumor.

\section{Pathological findings}

Histologically, the excised tissue revealed a well-differentiated intraosseous neoplasm, replacing the bone marrow and consisting of a large number of mature ganglion cells in a moderately cellular stroma of spindle cells (Figure $2 a-f$ ). The ganglion cells were large and in clusters, or randomly scattered, containing variable chromophylic/Nissl sub- 


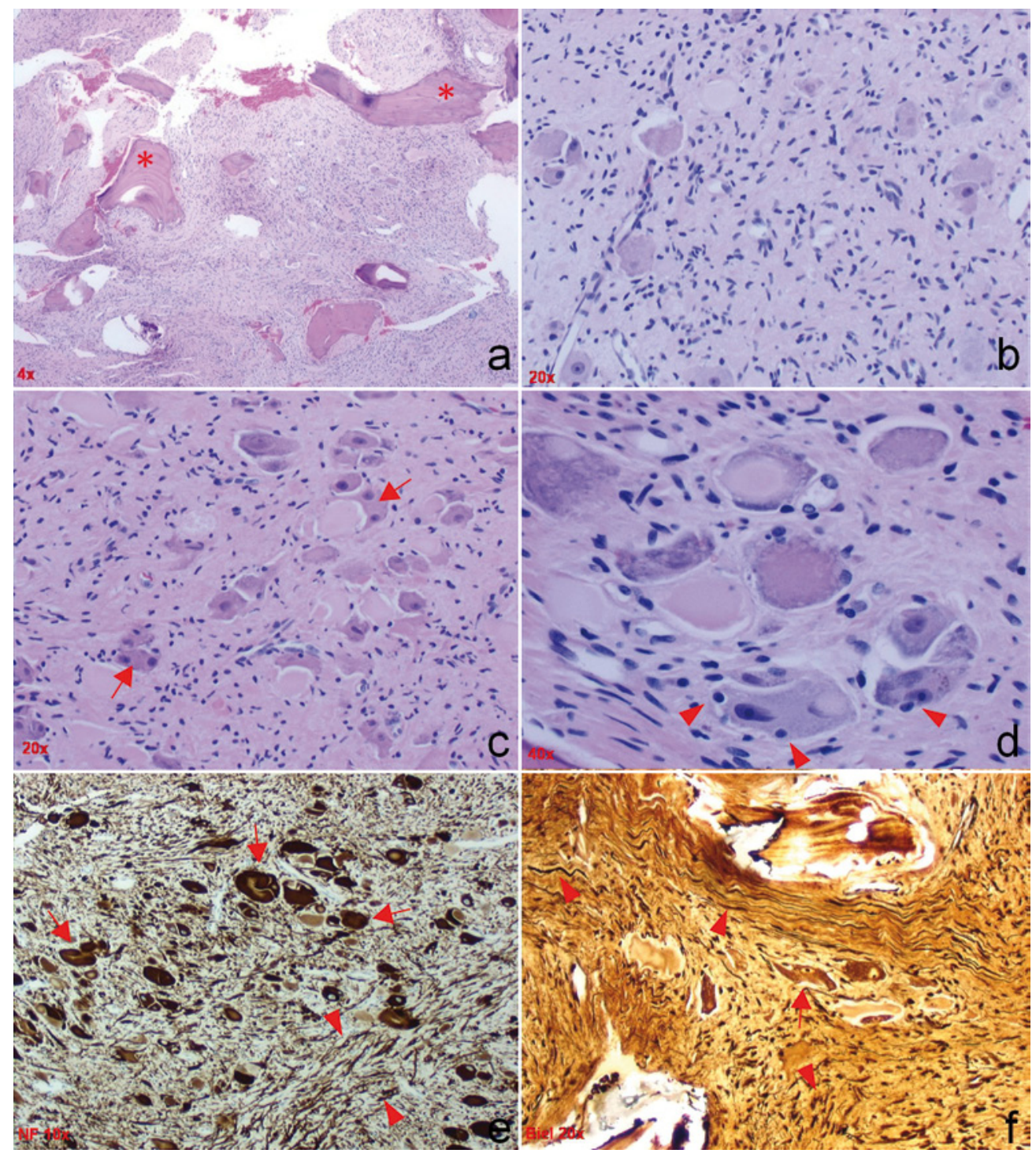

Figure 2. a: H\&E stain at low $(4 \times)$ magnification reveals an intraosseous tumor of moderate cellularity and boney specules, marked by asterisk. b: At higher magnification $(20 \mathrm{x})$, randomly distributed large and dysplastic ganglion cells are seen in a background of neoplastic spindle cells with scant cytoplasm. c, d: $\mathrm{H} \& \mathrm{E}$ stains reveal irregular clusters of dysplastic ganglion cells with abnormal distribution of the chromophylic substance, binucleated cells (arrows) and infrequent satellite cells (arrowheads). e, f: At $10 \times$ magnification, the neurofilament (directed against $70 \mathrm{kDa}$ and $200 \mathrm{kDa}$ polypeptides of non-phosphorylated neurofilament) (e) and at $20 \times$ magnification, sections stained with silver (f) reveal bizarre and haphazardly oriented axons (arrowheads) as well as few large ganglion cells (arrows).

stance and rare cytoplasmic vacuoles. They revealed mildly pleomorphic, vescicular nuclei, occasional binucleation and paucity of satellite cells. Neuroblastic cells and immature neurons were absent in the lesion. The tumor revealed abundant elongated axons with Bielschowsky silver and lacked myelin with Luxol fast blue stain. The ganglion cells were positively immunolabeled with synaptophysin antibody and their processes stained with silver. The neurofillament antibody immunolabeled both cell bodies and processes of the ganglion cells. Normal ganglionic or peripheral nerve elements were not seen. Postsurgical neurological examination did not reveal any deficits. CT studies performed 2 months after surgery did not reveal residual or recurrent tumor.

\section{Discussion}

Ganglioneuroma (GN) is classified as a benign well-differentiated neoplasm of the peripheral nervous system (PNS) [2]. GNs are composed of mature ganglion and 
Schwann cells, and accurate diagnosis of GN without tissue examination is difficult [16]. Most often GNs are asymptomatic, incidental masses discovered on a routine radiographic study [17]. They become symptomatic when they compress and/or displace adjacent structures. The first documented case of GN was reported by Loretz in 1870 [18]. GNs are classically found within the posterior mediastinum $(41.5 \%)$, pelvis and retroperitoneum (the suprarenal medulla is a favorite site) $[1,2,3,4,11,13,16,19,20,21]$. These sites are usually associated with autonomic ganglia, especially sympathetic ganglia [1]. In our case during surgery, this intraosseous lesion was not noted to be contiguous with the pterygopalatine fossa, pterygopalatine ganglion or trigeminal (Gasserian) ganglion. Microscopy also did not reveal any peripheral nerve or ganglion. Rarely, GNs have been observed in the spinal cord, cranial nerve ganglia, mandible, tongue, parapharyngeal tissue, gastrointestinal tract, bladder, visceral ganglia, uterus, ovary, spermatic cord, testes, prostate, skin, and bone $[5,13,22,23]$. Involvement of the central nervous system (CNS) has been described but is extremely rare [3]. Keefe reported a case of left posterior cranial fossa GN and mentioned that 11 cerebellar cases had been reported up to that point [24]. Ozluoglu et al. reported a lesion in the internal auditory canal that presented with hearing loss [25]. In fact, based on available microscopic descriptions, most of the CNS lesions listed in the older literature very likely represent intracranial hamartomas or gangliogliomas, which are both lesions of the CNS and not the PNS. Lesions associated with the cranial vault have been reported in the temporal bone [26] and the orbital bone [7]. Also, there are case reports of lesions in the orbit [6,7], optic nerve and chiasm [27]. Our case is the first lesion reported in the greater sphenoid wing.

GNs are usually seen before the second decade of life and rarely after the sixth [4]. The median age at diagnosis has been reported to be approximately 7 years $(5.5-10$ years) [17]. There are different reports regarding gender predilection. Some studies reveal no gender predilection whereas some mention slight female predominance $[11,19$, 21]. Our case is further unique in that the GN is identified in a 35-year-old man without a prior history of neuroblastoma or association with a familial disorder, thus representing a case of sporadic benign neoplasm arising de novo in an unusual location.

Considering the radiological findings, age bracket, and the location of the lesion, our preoperative diagnosis favored intraosseous meningioma. However, microscopic tissue examination reveals typical features of a ganglioneuroma. GNs lack cellular atypia, mitotic activity, and necrosis [28], and overall have relatively better prognosis than most of the other tumors derived from the neural crest. Malignant transformation is very rare and total resection is the most important treatment modality. Radiation and chemotherapy have no role in the treatment of these tumors $[16,17,29]$.

In summary, cranial ganglioneuromas are extremely rare. Being benign tumors, grosstotal surgical excision is considered to be curative. However, clinical follow up of the patient is recommended since rare cases of malignant transformation have been reported. In this case report, we present the first case of ganglioneuroma involving the sphenoid wing.

\section{Acknowledgments}

The authors thank Traci Niesen HT (ASCP), Sally A. Drew MT (ASCP), and Linda A. Sebree HT (ASCP) for their excellent technical assistance, as well as Korise Rasmusson $\mathrm{PhD}$ and Gregory Kujoth, $\mathrm{PhD}$, for their assistance with preparation of this report.

\section{References}

[1] Burger PC, Scheithauer BW, Vogel F. S. Surgical pathology of the nervous system and its coverings. New York: Churchill Livingstone; 2002.

[2] Ghali VS, Gold JE, Vincent RA, Cosgrove JM. Malignant peripheral nerve sheath tumor arising spontaneously from retroperitoneal ganglioneuroma: a case report, review of the literature, and immunohistochemical study. Hum Pathol. 1992; 23: 72-75. doi:10.1016/0046-8177(92)90015-U PubMed

[3] Shin JH, Lee HK, Khang SK, Kim DW, Jeong AK, Ahn KJ, Choi CG, Suh DC. Neuronal tumors of the central nervous system: radiologic findings and pathologic correlation. Radiographics. 2002; 22: 1177-1189. PubMed 
[4] Weiss SW, Goldblum JR, Enzinger F. M. Enzinger and Weiss's soft tissue tumors. [St. Louis, Mo.]: Mosby/Elsevier; 2008.

[5] Mithöfer K, Grabowski EF, Rosenberg AE, Ryan $D P$, Mankin HJ. Symptomatic ganglioneuroma of bone. A case report. J Bone Joint Surg Am. 1999; 81: 1589-1595. PubMed

[6] Cannon TC, Brown HH, Hughes BM, Wenger AN, Flynn $S B$, Westfall CT. Orbital ganglioneuroma in a patient with chronic progressive proptosis. Arch Ophthalmol. 2004; 122: 1712-1714. doi:10.1001/ archopht.122.11.1712 PubMed

[7] Choi HY, Lee JH, Park JM, Shin MK. Orbital ganglioneuroma in a young healthy person. Arch Ophthalmol. 2009; 127: 223-225. doi:10.1001/ archophthalmol.2008.573 PubMed

[8] Qamouss O, Zoubeir Y, Oukabli M, Chahdi H, Harket A, Abouchadi A, Nassih M, Albouzidi A, Rimani $M$, Labraimi A. Ganglioneuroma of the zygoma. Rev Stomatol Chir Maxillofac. 2006; 107: 370-372. doi:10.1016/S0035-1768(06)77066-8 PubMed

[9] Burchiel KJ, Shaw CM, Kelly WA. A mixed functional microadenoma and ganglioneuroma of the pituitary fossa. Case report. J Neurosurg. 1983; 58: 416-420. doi:10.3171/jns.1983.58.3.0416 PubMed

[10] Robertson DM, Hetherington RF. A Case of Ganglioneuroma Arising in the Pituitary Fossa. J Neurol Neurosurg Psychiatry. 1964; 27: 268272. doi:10.1136/jnnp.27.3.268 PubMed

[11] Modha A, Paty P, Bilsky MH. Presacral ganglioneuromas. Report of five cases and review of the literature. J Neurosurg Spine. 2005; 2: 366-371. doi:10.3171/spi.2005.2.3.0366 PubMed

[12] Cushing $H$, Wolbach $S B$. The transformation of a malignant paravertebral sympathicoblastoma into a benign ganglioneuroma. Am J Pathol. 1927; 3: 203-216.

[13] Jain M, Shubha BS, Sethi S, Banga V, Bagga D. Retroperitoneal ganglioneuroma: report of a case diagnosed by fine-needle aspiration cytology, with review of the literature. Diagn Cytopathol. 1999; 21: 194-196. doi:10.1002/(SICI)10970339(199909)21:3< 194::AID-DC9 > 3.0.CO;2B PubMed

[14] Shimada H, Ambros IM, Dehner LP, Hata J, Joshi $V V$, Roald $B$. Terminology and morphologic criteria of neuroblastic tumors: recommendations by the International Neuroblastoma Pathology Committee. Cancer. 1999; 86: 349-363. doi:10.1002/ (SICI) 1097-0142(19990715)86:2 < 349::AIDCNCR20 > 3.0.CO;2-Y PubMed

[15] Lucas K, Gula MJ, Knisely AS, Virgi MA, Wollman $M$, Blatt $J$. Catecholamine metabolites in ganglioneuroma. Med Pediatr Oncol. 1994; 22: 240-243. doi:10.1002/mpo.2950220405 PubMed

[16] Leeson MC, Hite M. Ganglioneuroma of the sacrum. Clin Orthop Relat Res. 1989; 246: 102-105. PubMed

[17] Geoerger B, Hero B, Harms D, Grebe J, Scheidhauer $K$, Berthold $F$. Metabolic activity and clinical features of primary ganglioneuromas. Cancer. 2001; 91: 1905-1913. doi:10.1002/10970142(20010515)91:10 < 1905::AID-CNCR1213 >3.0.CO;2-4 PubMed

[18] Kaufman MR, Rhee JS, Fliegelman LJ, Costantino $P D$. Ganglioneuroma of the parapharyngeal space in a pediatric patient. Otolaryngol Head
Neck Surg. 2001; 124: 702-704. doi:10.1067/ mhn.2001.115371 PubMed

[19] MacCarty CS, Waugh JM, Coventry MB, Cope $W F J r$. Surgical treatment of sacral and presacral tumors other than sacrococcygeal chordoma. J Neurosurg. 1965; 22: 458-464. doi:10.3171/ ins.1965.22.5.0458 PubMed

[20] Maweja S, Materne R, Detrembleur N, de Leval L, Defechereux T, Meurisse M, Hamoir E. Adrenal ganglioneuroma. A neoplasia to exclude in patients with adrenal incidentaloma. Acta Chir Belg. 2007; 107: 670-674. PubMed

[21] Mounasamy V, Thacker MM, Humble S, Azouz ME, Pitcher JD, Scully SP, Temple HT, Eismont F. Ganglioneuromas of the sacrum-a report of two cases with radiologic-pathologic correlation. Skeletal Radiol. 2006; 35: 117-121. doi:10.1007/ s00256-005-0028-6 PubMed

[22] Duffy S, Jhaveri M, Scudierre J, Cochran E, Huckman $M$. MR imaging of a posterior mediastinal ganglioneuroma: fat as a useful diagnostic sign. AJNR Am J Neuroradiol. 2005; 26: 2658-2662. PubMed

[23] Freeman BD, Zuckerman GR, Callery MP. Duodenal ganglioneuroma: a rare cause of upper GI hemorrhage. Am J Gastroenterol. 1996; 91: 2626-2627. PubMed

[24] Keefe JF, Kobrine AI, Kempe LG. Primary ganglioneuroma of the posterior cranial fossa: case report. Mil Med. 1976; 141: 115-116. PubMed

[25] Ozluoglu LN, Yilmaz I, Cagici CA, Bal N, Erdogan $B$. Ganglioneuroma of the internal auditory canal: a case report. Audiol Neurootol. 2007; 12: 160-164. doi:10.1159/000099018 PubMed

[26] Kinney SE, Sebek BA. Rare tumors of the skull base and temporal bone. Am J Otol. 1985; 6 (Suppl): 135-142. PubMed

[27] Cogan DG, Poppen JL, Hicks SP. Ganglioneuroma of chiasm and optic nerves. Arch Ophthalmol. 1961; 65: 481-482. PubMed

[28] Joshi VV. Peripheral neuroblastic tumors: pathologic classification based on recommendations of international neuroblastoma pathology committee (Modification of shimada classification). Pediatr Dev Pathol. 2000; 3: 184-199. doi:10.1007/ s100240050024 PubMed

[29] Goldman RL, Winterling AN, Winterling CC. Maturation of tumors of the sympathetic nervous system. Report of long-term survival in 2 patients, one with disseminated osseous metastases, and review of cases from the literature. Cancer. 1965; 18: $\quad 1510-1516 . \quad$ doi:10.1002/10970142(196511)18:11< < 1510::AIDCNCR2820181124 > 3.0.CO;2-H PubMed 